\title{
Tattoos and tableaus of flourishing: Qohelet and African spirituality in transformation
}

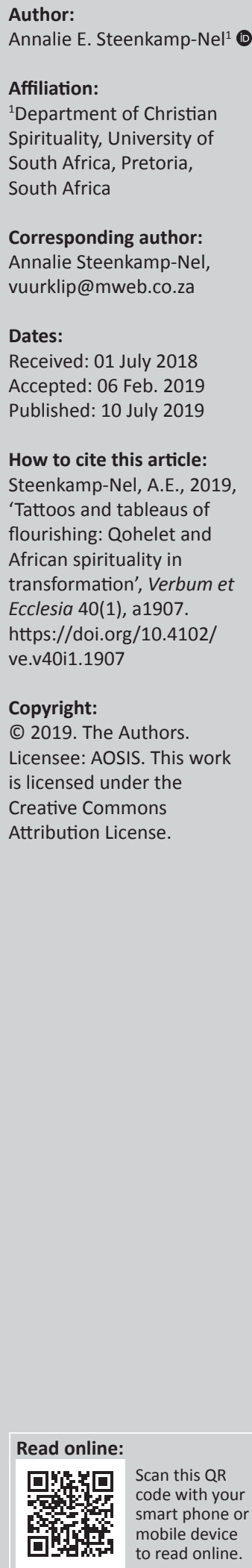

\begin{abstract}
African spirituality studies have established that Africans regard flourishing as connected to the secular and the sacred. African human flourishing as a multi-faceted concept remains relatively unexplored though. Guided by a spiritual transformation approach, I suggested that African lives, activities, choices and beliefs are dynamically integrated with Qohelet's interpretation of joy towards flourishing. I offered differing interpretations of familiar 'joy' texts in Qohelet in an effort to breathe new life into the texts themselves, along with the interdisciplinary dialogue more generally. The theoretical framework of spiritual transformation will be followed in order to relate 'flourishing' and 'joy' to its African relevance. The interaction between Biblical scholarship and African spirituality resulted in attaining a more profound understanding of the African human person. African spiritual transformation and its Biblical resonances can guide readers in harnessing their own range of joy experiences, unravel daily issues and enhance modern flourishing.
\end{abstract}

Intradisciplinary and/or interdisciplinary implications: The research is positioned in the interface between Biblical scholarship and African spirituality. The sensorial aspect of joy can be explored in Liturgy and Practical Theology in order to assist churches in accommodating joy. Spirituality can support Missiology on its way to congregational and community flourishing. The constructive engagement with the natural sciences can assist diverse societies, individuals, families, biological bodies, social groups and political institutions in South Africa to understand with integrity the origin and ongoing dynamics of their spirituality.

Keywords: African spirituality; flourishing; joy; Qohelet; spiritual transformation, decolonisation, Old Testament; Ecclesiastes.

\section{Introduction}

To the question 'why does Africa not flourish?', there is no shortage of solutions being offered. One of humanity's main facilitators that promote international cooperation, the United Nations Population Fund (UNFPA), came, in 2016, to the conclusion that to flourish sustainable development requires spiritual transformation on individual, societal, global and ecological levels (UNFPA 2016: $2,7)$. Implementation was only on methodological, structural and strategic transformation levels though (International Peace Institute 2016:1-23) and the emergent construct spiritual transformation was left behind. It is not a surprise. Rarely the Bible and Africa are seen in tandem as a source of theory for flourishing. Even among theologians (Pennington 2015b), pastors (Adams \& Bloom 2017:254-259), economists (Crespo \& Mesurado 2015:931-946), psychologists (Fredrickson \& Losada 2005:678-686) and politicians (Sypnowich 2018:314-332), know how to precisely go about promoting human flourishing which is still a matter of debate. To detect flourishing, I will propose an overarching framework that 'can respond profoundly to the aspirations for and the dilemmas of human flourishing' (Lincoln, McConville and Pietersen 2013:xiii), namely Qohelet ${ }^{1}$ and modern $^{2}$ African $^{3}$ spiritual transformation. I will lastly examine cross-sectional associations. My purpose is not to rescue either of the two, Qohelet or African spirituality, but to propose, not unlike a sfumato ${ }^{4}$ artist, a more nuanced approach to flourishing. Spiritual transformation through joy can enrich,

1.Qohelet is the Hebrew name or title of the book Ecclesiastes (Greek), meaning 'member of the qahal or congregation. It could also refer to one who addresses a congregation or 'preacher' or "gatherer" of statements or aphorisms collected in a book (Garfinkel 2011:215).

2.Modern African spirituality is here understood as an 'interpretation/expression of, or in interaction with its biblical heritage' (Lombaard 2003:218).

3.I would like to preface this article by stating that although I am not a member of the African culture, I endeavour to discuss - with a degree of humility - the nuances of African spirituality in a way that is both faithful to its people and easy for the uninitiated/ unacquainted to comprehend.

4.Sfumato is a painting technique adored by Da Vinci, who described it as 'in the manner of smoke', inexact and undefined, beyond focus, a hazy impression, glanced at sideways. This is a fitting for joy 'whose scents waver hazily at the edge of conscious awareness, tip-toeing the upper edge of our subconscious' (Sfumato 2017). 
rebreathe and amplify the discourse (United Nations 2015:129) on human flourishing.

\section{Spiritual transformation in Qohelet}

How is Qohelet and African spirituality interested in flourishing? To the question of human flourishing, Qohelet is no stranger. To help us understand the concept more clearly, as I will be talking about 'flourishing' throughout this article, 'flourishing' in Hebrew, shalom, means:

universal flourishing, wholeness and delight - a rich state of affairs in which natural needs are satisfied and natural gifts are fruitfully employed, a condition that inspires joyful wonder as its Creator open [sic] doors and welcome [sic] the creatures in whom he delights, the way in which things ought to be. (Platinga 1995:10)

(For a complete account of the flourishing construct in the Old Testament, see McConville 2013:57-58. Flourishing as resilience is outside the scope of this article). Considering the above rich context, Qohelet (as part of Biblical wisdom literature) addresses readers accordingly, not as a 'specialized boutique interest' (Pennington 2015a) but as grass roots spirituality. 'To forsake what is harmful to one's well-being and embrace a way of life that will enable one not only to cope with perplexing realities but to flourish as human beings' (Lee 2005:10,126) is Qohelet's ultimate objective. This view stems from Qohelet's own spiritual journey. Based on this observation, the theoretical framework of spiritual transformation will be followed in order to relate 'flourishing' and 'joy' to its African relevance.

Although Qohelet's journey to flourishing was deeply transformative, ${ }^{5}$ his journey was not formatted, parcelled or complete but an 'unfolding experience' (Lombaard 2015:3). The author(s) moved through stages or movements characterised by subtle adjustments. An example is the unfolding of his understanding of joy because of his unfolding understanding of God (Sekine 1999:118). How did he understand God? In earlier Jewish thinking (Old Testament OT), institutionalism (temple) and legalism (torah) guaranteed God's rewards or punishment (Sekine 1999:126). Salvation was synonymous with slavish obedience. God was rituals and rules (Perdue 2008:252) (see Figure 1). Then a series of new outer horizons ${ }^{6}$ came into view. Israel became, over many decades and under the auspices of various empires (Assirian, Egyptian, Babylonian, Persian and Greek), a sort of ethnic province or colony. ${ }^{7}$ As each horizon brings its own scenery, each empire brought its own adversities, possibilities and trauma for the local inhabitants. For Israel the changing sceneries of different colonisers brought death in many

5.1 discussed the construct of spiritual transformation in detail. I use the term for the process of restoration of the divine-human relationship. It goes one step further than transformation on its own: it is transformation by God leading to unlimited possibilities (Steenkamp-Nel, 2018a:261-277; Rahner 1984:61).

6.Waaijman (2007:3) distinguished two horizons: an outer and an inner horizon. The outer horizon is a person's context: historical, socio-psychological, economic and cultural environments. The inner horizon is the configuration of one's spiritual transformational experience being practice of virtues, prayer practices (Van den Hoogen 2011:101; Waaijman 2002:3).

7.This article is of the view that Qohelet reflects on the contact Israel had with surrounding cultures in different historical contexts.

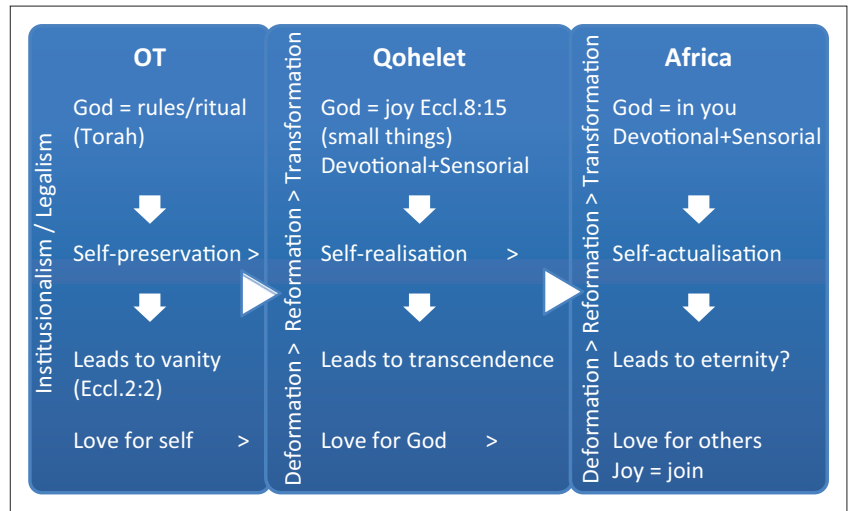

OT, Old Testament; Eccl., Ecclesiastes.

FIGURE1: Spiritual transformation in Africa in relation to joy in Qohelet: Stages or movements.

forms. At this point, before addressing the effect of trauma, I will indicate the levels of death that they experienced. Firstly, they experienced a variety of collective losses (follow the Babylonian exile). Secondly, the socio-economic order capsized $(3: 16 ; 10: 7)$. Thirdly, people were oppressed in the courts $(3: 16 ; 5: 8)$. Fourthly, the colonial beneficiaries drowned the local citizens' capacity through narrow prescriptiveness, that is, 'since you are in the dark, I will decide about opportunities, where, who and for how long' (4:1; 8:7-9). The locals' voices were, for instance, silenced and their influence was diminished by the official language of the state-Aramaic under Babylonian and Persian rules (Spolsky 2014:39-44), and later Greek under Ptolemaic rule. It set into motion the gradual loss of identity to such an extent that they 'could no longer read their own Scriptures' (Lewis 2018). In fact, Jesus' home language was centuries later, according to Ong (2012:67, 93) probably (Babylonian inherited) Aramaic. Fifthly, the new indigenous elite exercised their power to victimise, divide, depress and oppress others (8:9) through new rules, ideas $(3: 9,5: 15,7: 27)$ and values of 'wealth, possession, money and riches' (2:1-8, 18-21; 4:7-8; 5:8-10, $12-15 ; 6: 1-2,7-9 ; 7: 12)$. Sixthly, the new dispensation brought about new social dynamics like spies, and labourers gossip (10:20), but also surprising opportunities (9:11, 13-15) and shocking outcomes $(5: 7-8 ; 6: 2 ; 7: 15 ; 8: 10 ; 9: 16)$ (for more details, see Seow 2008:198-255).

Now we can deal with trauma as part of an inner shift towards spiritual transformation. To understand the deep effect trauma had on Israel, we have to look at the evidence of their deformation. Qohelet mentions an 'inability to form meaningful relationships' (3:18-19) that indicate an inner woundedness and trauma not only existentially (Christianson 2007:136) but also as being emotionally stuck in a profound way. In the psychoanalytic method and discipline, it is described as a 'psychic disturbance' (Zimmermann 1973:xiii, 8), namely, an 'incapacity to move beyond cynicism and skeptical recommendations', and an aloofness that forms a 'barrier to real touch and genuine affection' (Fontaine 2000:114). It came in many forms. Firstly, human activity in Israel (1:14) was full of madness and folly (2:12). Riches hurt the ones who possess them $(5: 13)$. There was no ability to 
enjoy one's wealth (6:1-2). Class conflict was a common occurence (5:8-20). There was undoubtedly the fact that people were dying (12:3) (McCabe 1996:94). Some act out their brush-with-death $(4: 10)$. Noteworthy is how Israel became stuck in self-preservation through injustice in courts $(3: 16 ; 7: 15)$. In the seventh place, labour produced rivalry (4:4), unexpected victors (9:11) and, finally, inappropriate leadership (10:7) (McCabe 1996:94). Qohelet's readers and listeners experienced a world seemingly out of control. As a result, some Israelites encountered deformation. ${ }^{8}$ This anaesthetised state was preferable to the endurance of 'continuous emotional pain' (Fontaine 2000:114). The underlying layer beneath the text indicated by the repeated leitwörter of death and hebel [vanity] signifies the deformation (1:11; 2:2, 14-16, 3:2, 19-20; 6:6, 12; 7:2; 7:17; 8:13; 9:5; 12:6-7). Qohelet's description of Israel's spiritual aftershock is scientifically described by Fitzgerald's (2009) conversation with the psychosocial realities, particularly as they 'interface with memory and past experiences':

A Community that suffered victimization and persecution in the past can use remembering as a means of constructing and consolidating or as a means to tell the same narrative of anguish and justify perpetrating violence, hatred, oppression and even ethnic cleansing in the present. (p. 25).

With so much emotional turmoil, the restoration of the fragmented poor, poorly educated and agrarian nation was understandably slow, despite reverence for the Torah, and religious revival efforts (follow Nehemia). Pain is ex post facto layered, unseen, inaudible, sticky. This 'muted' experience made space for perceived finite straight lines to subtly cross and interweave. This gradual insight in the scenery(ies) or perceptions of pain set a different spiritual current in motion. It dawned on Qohelet that change takes time. Self-evaluation followed, then exploration, suddenly wonder, and subsequently new insights. An understanding developed that outer adjustments are inoperative. Rules guarantee nothing (Sekine 1999:126). Love for myself is vanity. Joy is not in things. God is not just rules (torah) and ritual (Lohfink 2003:57; Perdue 2008:253; Sekine 1999:26). God is joy. An inner reorientation followed. Qohelet began to commend joy while we are alive (McCabe 1996:110) in a transformational sense.

\section{Qohelet's transformational journey through joy}

So far we have traced that during Qohelet's spiritual transformation, his experiences led to the shedding of previous orthodox or traditional beliefs. They previously formed him, but no longer transformed him. Stagnant and obsolete

8.I distinguish between three types of spiritual transformation, following the work by Kees Waaijman, Spirituality: Forms, Foundations, Methods (Dutch, 2000; English translation, 2002). They are labelled deformation, reformation and transformation translation, 2002). They are labelled deformation, reformation and transformation. Deformation is conformity to the world. One has no prospects or hope, and is limited by people or situations or oneself, self-orientated and/or self-absorbing (Waaijman 2006:44, 460, 461). Reformation proceeds from God and entails renewal of the mind to distinguish what is good, distinguishable by action. Spiritua transformation is not linear. It is a process and individuals can oscillate between ecstasy and confusion, a feeling of nothingness but also triumph (Steenkamp-Ne 2018a:264). opinions that attenuated his inner horizon shifted to his outer horizon (Steenkamp-Nel 2018b). His text (religious convictions which are supposed to transform a person) became his context. To follow his journey I will use the leitwort, 'joy'. Although 'many different terms in the Bible related to happiness, joy, flourishing, well-being, and fulfillment' (Pennington 2015a), cognisance was taken in delimiting the boundaries of the study to one particular category of texts within the domain of wisdom literature, that is, Qohelet's 'joy texts', in order to gain some insights into the spirituality that lived behind Qohelet's 'textual veils' (Lombaard 2011:223). It is based on the following pathways, firstly, on a statement by Lombaard (2003:433-50) that the OT is 'itself a substantive part of present Christian spiritualities'. Secondly, a note was also taken that during the past two decades more attention has been given to the possibility that the Biblical wisdom or proverbs originated among the ordinary people and that their tribal context and indigenous wisdom are remarkably similar to many rural societies in Africa (Golka 1993:1, 6, 15, 16, 55). In the third place, Qohelet's spirituality of joy 'stemming from the life experiences of ordinary people', provides 'practical and compassionate ways on how a person may achieve the greatest human flourishing' (Lee 2005:125-126) in a time-bound and laborious (Enns 2011:55) world beyond human control (Lee 2005:124-126). Here is where the fourth pathway appears, namely, that the 'joy texts' (as lived expressions of faith) is the type most favourable to investigate the link between Qohelet and African spirituality because during Qohelet's 'intense spiritual experience' he arrived at new horizons, and reordered the 'great axes' of his spirituality 'in terms of his contemporary experience' (Peters 2013:79). Fifthly, that African spirituality and wisdom literature is both experiential means that 'like the Hebrews, the African perspective is experiential and holistic' (Long 2000:20). Moreover, wisdom literature draws from the well of experience (Lombaard 2015:90). A further delimiting of my subject follows from a sixth pathway, namely, that the joy kernels as part of the human experience occupy a central place and play a central role in Qohelet's meaning making (Fox 1989:11; James 1984:89). In the seventh place, joy is particularly appropriate because 'joy' is a poetic and wisdom-related word (Longman \& Enns 2008:80). The last pathway is that the process of spiritual transformation through joy can be applied to any subject and is especially suited for practical aspects of a subject.

We can say that as far as spiritual transformation is concerned, the construct of joy, as a 'metaphorical frame of reference', had undergone profound transformation in the book. What spurred Qohelet's re-alignment to God (reformation)? On the basis of the foregoing, I settled for two distinct joy experiences: joy experienced in a devotional sense and joy in a sensorial sense. This matter will now, in the following two sections, be taken into review, hoping that I will convey something of the essence of spiritual transformation's theoretical framework.

\section{Devotional joy}

In spite of studies which found Qohelet to be radical (Perry 1993:xi) or less rigid determinism (Fox 2010:197; 
Murphy 2018:lxvii), it is my aim to illustrate how spiritual transformation as a framework can serve as a springboard for stimulating further study to understand and implement Qohelet more accurately and usefully. One of the great strengths of the spiritual transformation framework is that its multidimensionality and novelty can preserve the integrity and variability of the text for much longer, crossfertilising linguistic approaches. Echoing and extending the notion that 'flourishing' is Qohelet's ultimate objective, there are many different terms in Qohelet related to flourishing, that is, 'eating, drinking, working, playing' (Lee 2005:138). ${ }^{9}$ They frequently appear across the book. 'Joy' is specifically used as a metaphor for flourishing and is within the mise-en-scène (arrangement) of human flourishing, a multifaceted concept ${ }^{10}$ suggesting a gradual loosening up and development of the construct in spite of accusations to the contrary (Walsh 1982:46,47). Joy can be translated from two terms and can be used twofold. Firstly, Simchah/26; $3: 12 ; 5: 19 ; 8: 15 ; 9: 7)$ describes the joyful state of one who 'cheers up' or 'makes merry' (Strong 1890:118). Then $R a^{\prime} a h /$ האָר (2:24; $3: 13 ; 5: 18 ; 9: 9)$ that encompasses an individual as well as a communal experience of joy, that is, to be 'joyfully present' (Strong 1890:106). Another translation of simchah can be 'favourable' because of the implementation of the merriment aspect of joy in everyday life, for example, 'bread to be eaten in joy' $(9: 7 ; 11: 1-2)$ as well as being given in hospitality that incorporates the communal embodiment of joy (Brown 2011:93, 129), an aspect that is later taken up in the Jewish Feast of the Tabernacles (Alexander \& Baker 2003:28, 30; Unger 2005:248-250). The second use of 'joy' is bound up with the community. The translation of ra'ah can be conducive for communal (Richards 2016) joy and contentment, that is, depicting work, eating and drinking, marriage and family $(2: 24 ; 3: 12-13,22 ; 5: 18-20 ; 7: 4 ; 8: 15$; 9:7-9;12:13-14) (which I will further discuss in the following section regarding the African transformational journey through joy). The third and related use is Qohelet's recalibration, namely '... that every man should eat and drink, and enjoy/flourish the good of all his labour, it [is] the gift of God' (3:12 King James Bible) (author's translation). Lastly, joy becomes joy when the above small things of everyday life are enjoyed because 'God is in the small joys of everyday life' (Sekine 1999:119). ${ }^{11}$

In Ecclesiastes 9:7-10, Qohelet's earlier commendations (2:24; 3:13) are converted into imperatives 'eat, drink and enjoy life' because repeating actions like eating, drinking and enjoying makes room to, at least for a moment, stop, to shift away from 'urgent and insistent demands', self-absorption, selfexpression and being less insistent in one's own needs, pain and demands. I would however differ from Fox (2010:240) who states that joy is a 'distractor'. I would rather say that joy

9.See especially Ecclesiastes 9:7: 'Go thy way, eat thy bread with joy, and drink thy wine with a merry heart; for God now accepteth thy works' (King James Bible).

10.Recurring themes and motives within the Biblical corpus have attracted much scholarship. However, I do not intend to step into phraseology. For more on this subject, see Granger and Meunier (2008) and Carasik (2003:5, 6, 7, 9).

11.This insight was triggered by the post-exilic realisation (reinforced by Hellenism's rising influence) of the exilic principle's deeper meaning: 'I am what I am' (Ex 3:14). For more on this, see Waaijman $(2002: 18,435)$ widened Israel's cultural understanding and catapulted their minds in new trajectories, that is, to adapt, give to charity (even if it seems like a long shot without expecting rewards), divide your merchandise, take chances, exploit possibilities and seize opportunities (11:1-6) (Fox 1989:273; Ricoeur 1977:25) and choose wisely (7:15-17; 8:10-15; 9:2-3; 2:24). By eating and drinking with others one is 'born into a new world' that points away from the self (Waaijman 2002:176) to the invisible things (Waaijman 2000:1241). From the discussion above, the devotional bearing of joy becomes clear. Hence, let us turn to joy in a sensorial sense.

\section{Sensorial joy}

Qohelet calls for joy in seven key texts (2:24-26; 3:12-13, 22; $5: 17-19 ; 8: 15 ; 9: 7-10 ; 11: 7-12: 7)$. To eat and drink while enjoying is an 'existential involvement in the God-given sanctification as perceived by the senses' and 'reformation at a sensory level' (Waaijman 2002:177, 462). The process by which humans inwardly know an interior from signs that have been given from without through our senses is called 'understanding' (Waaijman 2002:661). This orientation of the body assists humans to orientate their soul towards a realisation of God. 'I perceived that there is nothing better for them than to be joyful/flourish and to do good as long as they live', reflects Qohelet (3:11 English Standard Version). In a joy moment, Qohelet experienced how earlier fixed dogmas turn to vapour. For a brief moment, he became open to gradual transitions, juxtaposing arguments and paradoxes, and new ideas. This is fitting considering Israel's quest for meaning amidst the colonised reality of oppression and subjugation of the 'vulnerable, poor, weak, voiceless and less privileged' in Israel by the Neo-Assyrians, NeoBabylonians and Persians (Biwul 2017:9). The plight for joy as a sensorial alignment to God is confirmed by other sciences. Several neurobiological studies have asserted that 'oxytocin released by sensory or equivalent stimuli exchanged in social interaction' decreases stress (Dabrowska et al. 2011:1312-1326; Landgraf \& Neumann 2008:xi-xiii; Neumann 2008:858-865), promotes health (Hansenne 2005:321-327; Macciò et al. 2010:157-163), induces feelings of safety and support (Feldman 2012:381), increases both trust and empathy (Bartz et al. 2011:301-309) and concerns for others (Baumgartner et al. 2009:756-770). We should also mention that frequent contact with others' 'pace, rhythms, jokes, movements, behavioral mannerisms and verbal idiosyncrasies' (Feldman 2012:387) is critical for humans' adaptation to a social milieu (Feldman 2012:381-382). Sensorial joy, by definition, 'redescripts' reality (Hall 2006:198) and lifts the mind into creative spaces and possibilities.

There is thus a case to be made that Qohelet's joy was not apostasy, opportunistic nihilism or an early outbreak of antinomianism. Qohelet decontextualised joy's meaning and recontextualised it in his own as well as in Israel's sitzim-Leben. The book combined the devotional and sensorial aspects or tones of joy in order to create a fulcrum or a 
bridge-text (Faulstick 2014:305; Sekine 1999:126) between two spiritual seasons ${ }^{12}$ (see Figure 1). Qohelet's spirituality of joy gives us a view of a future horizon. In this sense, it relates closely to flourishing discussed above. Let us now turn to exploring African spirituality's understanding of joy en route to flourishing. I will indicate that African spirituality is undertaking a spiritual journey in which their experiences foster profound transformations. I will show that African spiritual transformation goes through different forms (or stages). We will keep in mind that on this inner horizon Africans encounter reformation and deformation on their way to transformation. Let us listen to what they say, followed by a discussion on an African understanding of joy.

\section{Spiritual transformation in African spirituality}

So far, we have focused on how joy as an aspect of spiritual transformation effectuates Qohelet's flourishing. The aim of this section is to explore how the construct of spiritual transformation effectuates the African concept of flourishing. Before I touch on joy, a look at recent research, primarily conducted in Africa, on spiritual transformation and flourishing is necessary. The following reflection will render some key potentialities and enriching twists, at once surprising and familiar, to the spiritual pathways, adding value and refinement to our understanding of spirituality. I will use light and shade rather than lines to define the African spiritual landscape.

Human flourishing in Africa is a multi-faceted concept. There are many different terms related to flourishing, that is, 'interconnectedness' (Ubuntu), 'transformation' and 'joy'. In contrast to individualistic Western cultures, flourishing in African cultures does not hinge on living conditions. The sacred and secular worlds rather mutually influence each other (Mulago 1991:119-120), are extensions of one another (Beattie 1980) and are intricately intertwined (Ngong 2010:1). As Favor states: 'God is woven into the texture of my life' $(2004: 244){ }^{13}$ This interconnectedness has an additional horizontal relational aspect. Formal and informal caring and connectedness between humans enhance human flourishing (Marais 2016:237). 'One can empathically imagine the deep joy of another only to the degree to which one can access the grace and love of God in one's own experience', says Moschella (2012:8). For an African to take note of this interconnectedness is to flourish.

There are gaps between rhetoric and reality. Although the 'different areas of life, like the religious and the secular, the spiritual and the material', can in Africa 'never be compartmentalised and understood in isolation from one

12.A fulcrum is the point against which a lever is placed to get a purchase, or on which it turns or is supported, a thing that plays a central or essential role in an activity, event or situation (Stevenson 2010:706).

13.Although the Bible holds a central place in contemporary African Christian life and thought (Mwombeki 2001:121-128), it is the general take of this article that African Christian spirituality is still rooted in African spirituality (Froise 2005:56-59; African Christian spirituality is still rooted in African spirituality (Froise 2005:56-59;
Van Dyk \& Nefale 2005), that is, 'African traditional believes to an extent' (Knoetze 2015). another' (Brand 2002:103), for ordinary South Africans the continuous changing scenery of different outer horizons over the centuries brought deformation in different forms. Focusing on the present, I would explain a few modern examples. Firstly, the outer horizon of everyday illness and brokenness decreases life daily. The collapsing health system (eNCA 2018; Steenkamp-Nel 2018a:261-277) contributes to deformation by reducing patients' participation in healing and impairing wholeness and growth (Steenkamp-Nel 2018c, Dube 2006:134). Secondly, one in three South Africans has a lifetime mental disorder. ${ }^{14}$ Thirdly, one in three illegal drivers' licenses contribute to the country's rising death toll (Hlatshaneni 2018; TimesLive 2018). Fourthly, the decline of infrastructure (Van Zyl 2017) hinders productivity and growth. Fifthly, death in and of neighbourhoods (ExpatCapetown.com 2018) as crime 'refugees' flock to the 'safer' southern provinces (Property 24, 2018). In the sixth place is the deformation of fairness. Considering that postcolonial South Africa has a conflict-ridden and polarising socio-political and historical background, many sectors of the society resort to oversimplified solutions and lofty, progressive policies. Allow me an example. In pursuance of the 'undoing' of painful past policies (with a view to gear the nation towards supporting and managing diversity) is the adoption of Anglicisation in the legal system. Although the alleged decision was made public in a national newspaper, and not in the government gazette (Batt 2017), this arrangement leads to the fact that the poor and the poorly educated have to pay for the translation of sections of court records to English for judges of the Appeal Court if they want their cases to be heard (Chabalala 2017). It is to the detriment of the development of indigenous languages' 'modern scientific legal vocabulary' (Harms 2012: 23, 24) and contributes to deformation. Seventhly, the present intended and unintended colonial linguistic miasma (in spite of the decolonisation discourse) is enervating education. To give an illustration of what I mean, let's look at the case of pedagogical research that found that most pupils who want to get access to the progress and privileges of the black elite through English (Sakati 2016:3) have difficulty in coping. Eighthly, the government's romanticisation of English, notwithstanding the unfavourable outcomes of other than mother tongue education in primary schools (Desai 2012:ii, 226-227, 2016:350; Nomlomo 2008, 2009; Sakati 2016:113), high school and tertiary institutions, has 'dire life-long economic and social consequences, both for the individual and communities' (Van Staden \& Howie 2012:96). This is the case in spite of the state's noble intention to integrate society and redress past inequities. In the ninth place, there is deformation through fundamentalism, injustice and interpersonal violence. The recent higher education mother tongue debate is a case in point. African students have the assumption that the academic playing field would be levelled by preventing

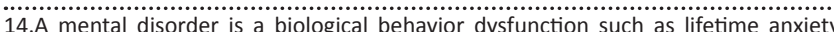
disorder, mood disorder or substance use disorder (Gureje et al. 2006:465-471; McEwan 2003:739-757). It leads to significant distress (e.g. a painful symptom) or functioning impairment and can be caused by mos and . Abrahams \& Mathews 2009:1-2; Kirmayer et al. 2000:609; Magwaza et al. 1993:795-803; McEwan 2003:739-757. 
minority language speakers from studying in their mother tongue (AfriForum and Another $v$ University of the Free State 2017; Jansen 2013:4). ${ }^{15}$ This linguistic clone-colonialism sets, as a visual non-sequitur, deformation (as retracting human potential) in motion, as illustrated by Mosibudi Mangena:

The language of debate in parliament and of doing state business must be colonial, and the fact that the majority of the people understand neither the language nor the colonial way of conducting business does not matter ... The languages of the colonisers ... are a mark of success, class, civilisation and a vehicle to access resources (Tsimane 2010).

The interconnectedness between the secular and the sacred is indeed broken (Masango 2006:932). Amidst much turmoil and pain, and anticipated future pain, the flourishing of the poor, and poorly educated, is and will be understandably slow despite reverence for the spiritual. God seems indeed to be lurking behind everyday life. This should not derail us. Spiritual transformation towards flourishing (as unlinear process) takes place at the frontiers of 'partial visibility, misunderstandings, reciprocal fetishisms, unwritten agreements, unruliness, protean arrangements' (Comaroff \& Comaroff 2012:116), and forceful techniques. The fusions of opposites, on the other hand, can fuel creativity and innovation, and can as such be a perfect petri dish for flourishing (follow Steenkamp-Nel 2019).

The main question to ask is how the trauma tattoos, on young and older bodies and minds, causing the scratching and acting out of deformation against others, can be overcome? Rocky backgrounds will not be overcome by stereotypical, lifeless caricatures and mundane portraitures. What South Africans need is perspective, and well-rounded arguments. Perhaps there is, like sfumato, no neat boundary but rather a blending of smoky tones and smudging edges. To glimpse effectively (inasmuch as it is possible) through the smoke and mirrors, it becomes necessary to balance bright contrasts of gaudy tints with soberer subtlety. Keeping in mind that Africa does not need putrid renarration, hard lines, catch-up or tired solutions and that possible (re)solutions lie deeper than the obvious, it is necessary to understand the African person processually.

\section{The African transformational journey through joy}

So far we have traced that African spiritual transformation is not linear. Deformation takes place in many forms. A different spiritual current is albeit already in motion. Reformation takes place in many forms. Some texts are already their context. Firstly, it is simultaneously dawning (Chung 2018) and inspiring that change in Southern Africa takes time.

15.This view has reached its apogee (outermost point) though. There is a growin awareness that the origin and use of the youngest language on the African awareness that the origin and use of the youngest language on the African continent, since its inception, were and still is multi-faceted, complex, and spoke by European Africans and people of colour alike. One of the earliest examples is the Arabic-Afrikaans alphabet that consisted of 29 letters in Arabic, developed and used since 1868 (van Selms 1951). Different cultures sharing this language even share a rich cooking heritage namely, amongst others, the fusion of Southern Eastern, European and African flavours and techniques in the form of 'kaneelsuike pannekoek' (cinnamon-sugar crêpes).
Follow the African saying, in line with ancient traditional belief, from Zaire:

Let the elephant fell the trees, let the bush pig dig the holes, let the mason wasp fill the walls, let the giraffe put up the roof, then we'll have a house. (Van Heerden 2006:435)

Secondly, the African perspective, since antiquity, embraced the process of flourishing as multi-dimensional (understood as wholeness). By way of illustration, let us consider the African holistic approach regarding healing. Healing is regarded as curative but not just curative. Death itself can also be regarded as a form of healing when a suffering person dies with a sense of inner peace and reconciliation with God. Healing in that sense can be understood as shalom (Mashau 2015:7). In the same trajectory, from a medicinal perspective, Kolk confirmed the above, namely, that the use of just powerful medications to lower the score of brokenness pharmacologically is obsolete (2015:e118-e119), pointing to the African integrated belief that the spiritual is also important. Thirdly, instead of closing, some Africans are opening themselves up to change. This openness is verbalised by a domestic worker. Ann (57 years, single) indicated: 'I thought they would reprimand me if I break something ... but I got the good people ... they say "No, it was an accident" ... they were friendly' (Marais 2016:242). Africans transformed are indeed more flexible, and with a vision wider than the seemingly present deformation. Let us have another example. Azania expressed a concern for fellow-humans and motivates others to act on that basis. She says:

Some contribution by the black elite to the township, taking that one poor and hungry child to school, would not be such a bad idea. After all, most of you were that child in the not-so-distant past. (Azania 2013)

Fourthly, to unravel trauma is not a quick fix. Africans embrace the very essence of the gradual nature of flourishing and use it interchangeably with salvation (Brand 2002:104). Salvation, in turn, acquires a 'gradualist' or processual quality - for therein '[o]ne is not "saved" or "unsaved"', but 'participates in salvation to a greater or lesser degree' (Brand 2002:106). Much the same can be said about spiritual transformation - here understood within Manala's (2006) concise formulation of the healing process:

Health is the making whole of persons in every part of their being i.e. the restoration of one's physical health, one's relationship with God, re-establishment of one's normal life functioning. The ultimate goal is the glory of God and the promotion and maintenance of human joy, peace, and harmony. (p.151)

This section has shown that to understand the African person is to understand him or her processually. Therefore, although South Africa bears the imprint of varied outer horizons, and coarse-grained dispensations, flourishing will not be achieved through hard lines, and detailed realism, but rather by the above nuanced sfumato of spiritual transformation, that is, gradual inner change. Borrowing knowingly or unknowingly from Qohelet's 'interpretation 
frame' (Frederiks 2005:108), some Africans hitherto do that already through a process of experienced existential transformation. Although many different terms in African spirituality relate to flourishing, cognisance was taken in delimiting the boundaries of the study to one particular term, that is, 'joy', in order to gain some insights into their spirituality. This will be discussed now in the following two sections.

\section{Devotional joy}

The previous section has so far traced spiritual transformation in an African context. I indicated that Africans encounter not only deformation but also reformation towards flourishing. We will now look at their spiritual transformation through the lens of joy. The African community experiences the 'joy texts' as 'instructive to their lives and life-situations' (Lombaard 2015:4) by means of selective-creative and pragmatic-playful hermeneutics (Maluleke 1996:13; West $1997: 105,114)$ understood processually. Let me take two examples. The experience of coming into God's presence, for instance, is embodied by joy (Paynter 2003:176). 'May you, o Lord, be for us a moon of joy and happiness' is the prayer (King 2003:21). Africans also believe that, because humans were made in the image of God, they cannot escape God; neither can they find 'joy and fulfillment apart from the Transcendant Being' (Gehman 2005:354). Joy is the expression of the Spirit:

The spirituality of joy is the conscious or unconscious experience of the Spirit setting you free from within. ... you irresistibly experience and express this inner freedom in spontaneous joy. (Hevi 2005:100)

Devotional joy is symbolised in everyday life. The 'five tufts' (of hair) symbol is said to be Africa's antique hairstyle of joy. It also represents the devotion and faithfulness one displays when doing a task required of one. 'Mpuannum' means loyalty or the embodiment of lofty duty to a desired goal (Willis 1998). To be joyful is to be grateful (Louw 2012:83, 188, 195). 'Everywhere in the world joy is the true expression of gratefulness. But not everywhere are the faces of God's children as transparent to that joy as in black Africa' (SteindlRast 1984:18).

The enjoyment of life implicates that a person is aware of the value which gives joy to life and how to pursue this, especially being the master of life, as a person in the milieu of community and society. (Bhengu 1996:64)

Furthermore, Africans not only read the Bible critically (Akper 2005:7), in a socio-political transformational sense, contextually or with a commitment to the Bible community (West 1992:10-11), but also read the Bible in a spiritual transformational sense. Their religious feelings are:

[...] deep emotions of joy and sorrow, fear and respect, guilt and remorse. Emotions often provide support for people, assuring them that traditional beliefs are true; convincing them that they are wrong in their behaviour and need to submit to the advice of the diviner and follow the traditions of the ancestors. (Gehman 2005:29).
The joy experience is existentially transformative insofar as it thrusts into consciousness the givenness of God. Africans in exuding joy show the face of God (Magesa 2010:178). Joy, so much joy - it is a key element in African worship (Zamarron 2013). Joy as a devotional act in African spirituality speaks clearly. That brings us to another way in which they engage with the Bible, that is, in a sensorial way.

\section{Sensorial joy}

Spiritual transformation, not only in Qohelet but also in African spirituality, is possible in different permutations (alterations/change/transformation). I beg to differ with Fox's and Lee's theological claims, unlike Lohfink (1990:625635) that joy is 'idiosyncratic' (Fox 2010:240) and even 'dangerous' (Lee 2005:4). Joy may be partly idiosyncratic (1 Cor 3:19) but it is also personalised revelation. In the Tshivenda culture, white symbolises joy (Nengovhela 2010:20). One of Africa's creation stories records the joy of colourful creation:

God made humans out of clay of different colours ... Then he gave humans legs with which to walk and run, hands with which to plant grain, eyes with which to see that grain, and a mouth with which to eat it. Afterwards God gave them the tongue with which to sing and talk; and finally ears, so that they may enjoy the sound of music, of dance, and of the talk of great persons. Then God sent humans out, each a complete human being. (Mbiti 2013:44)

To experience God through sight is not as Fox (2010:240) stipulated, an 'extraordinary experience'. It is intense living (see footnote 13). To be aware of the visional aspect of joy, one might even be, like C.S. Lewis, sensorially 'surprised by joy' (Lewis 1955:38-39). In conjunction with the experience of joy through colours Africans experience joy through their hearing. The citing of relevant proverbs during sermons that stir the imagination helps them to understand, remember and agree with the message being proclaimed (Moon 2009:178; Pobee 1997:54). As such, joy is an indicator as well as a conductor of flourishing.

Eating and drinking with joy, in addition, has a transformational aspect in Africa. The following will serve as an illustration. Exclusion from a family meal signifies a broken relationship (Healy \& Sybertz 1996:256). On the other hand, when two or more persons eat or drink together from the same plate they enter into a covenant or agreement, namely, that sharing a meal affirms and reaffirms the 'holy value attached to life and unity in relationship' (Onwu 1987:151-52). Sight, hearing, smell, taste and touch that cause joy create a transformational space for the Spirit to work in. The Spirit helps to overcome 'differences between the very different Other and the other' (Boyce-Tillman 2007:1411, 1413). In this space, stagnant and obsolete opinions that attenuated the inner horizon shift to the outer horizon. Ideas and beliefs, which previously formed one, no longer transform you. You gradually begin to see a person not for who he or she is but for who they can become. Their contribution and how he or she can give 
meaning to others' lives become important. You no longer scratch on others and refrain from hard outlines. Brush strokes are done with a soft touch and empathic contours. It is a view that spans over outer horizons into future years made possible by joy that imperceptibly yet inexorably expand a person into an all-encompassing spiritual space where, through the senses and relationships, God penetrates the 'pulse of life' (Block 1949:233). Kenosis become koinonia. Joy becomes 'join'. That in the African experience is spiritual reformation. That is also African holism, in a transformational dimension. It is in order to make space for flourishing.

There is hence a case to be made for a 'rereading' of the 'joy' texts through African eyes, namely, that joy, in communal or relational experiences, deconstructed, is devotional and sensorial. Sensorial and relational joy is reformational and as such a way out of deformation. To experience joy is thus to flourish. Next, the convergence of African spirituality and the transformational bearing of the joy text of Qohelet will be considered.

\section{African spiritual transformation in relation to joy in Qohelet}

The aim was to effectively deconstruct and interpret Qohelet's concept of joy in order to effectuate a comprehensive and integrated understanding of the African concept of flourishing. Having outlined joy in, or more to the point, behind, Qohelet and African spirituality, some possibilities for comparison now present themselves. It cannot be done exhaustively within the usual constraints applicable here, but at least the door is hereby opened to the conclusion reached after indicating the following parallels: firstly, although the contexts differ strongly, spiritual transformation relates to: the African holistic/wholeness perspective which fits into and mirrors Qohelet's gradualist approach to life. Secondly, Qohelet's audience being bound to the past, remembering wrongs, hampered moving on. In African spirituality collective memory of emotional trauma, it has to be acknowledged, leads to deformation and is hindering human flourishing. Thirdly, deformation does not imply permanent 'stuckness'. In both cases, spiritual transformation effectuates a progressive disconnection of the self in 'exchange' for God. Fourthly, an African person relates closely to flourishing per Israel's definition of 'shalom'. God is for both the raison d 'être [purpose] for devotional joy and a reverent acknowledgement of God puts them en route to a flourishing life. Joy is therefore grounded happiness. Fifthly, Qohelet's Hebrew and African audience draw on their experience of joy as revelation, not in a linguistic or exegetical sense but rather as a participatory opening up of possibilities until full(er), deep(er) knowledge and articulation begin to appear. Sixthly, in both cases joy is a devotional as well as a sensorial part of life, which is an indication of the interconnectedness between the sacred and the secular. To eat, drink and enjoy is sensorial reformation on its way to spiritual transformation.
For Africans everyday joy in a devotional and sensorial sense becomes 'Scripture' (Schneiders 2005:5, 11).

By comparing aspects of Qohelet and African spirituality, insight was gained into the dynamics of spiritual transformation evident in both African and Qohelet's spirituality. The two are indeed mutually conversant with one another. The implications are far-reaching. Diverse societies, individuals, families, biological bodies, social groups and political institutions in South Africa need a reference that will help them to think and understand with integrity the origin and ongoing dynamics of their own spirituality and spiritual reflection. In our post-modern world where God is experienced as mostly ineffable and unworded, these two spiritual journeys' re-alignment to God can be experimentally tried and tested, followed and practised until the 'joy texts' become one's context. The sensorial aspect of joy must be explored in Liturgy and Practical Theology to assist churches on how to accommodate joy ritually as well as liturgically. Church planting and missionary thinking is good. It has however to be followed up with spiritual transformation towards individual flourishing on its way to congregational and community flourishing. This will subsequently provide insights into ways people can optimise joy and more consciously accommodate merriment in their get-togethers. A spiritual transformation framework without the usual borders will be constructive decolonialisation, which can suitably accommodate dimensions valued by African spirituality so that Africa and the world can flourish (more). Sustainable (spiritual) flourishing requires 'spiritual transformation' on individual, societal and global levels. A journey through joy is a jo(urne)y.

\section{Acknowledgements Competing interests}

The author declares that she has no competing interests with regard to the writing of this article.

\section{Authors contributions}

A.E.S.-N. is the sole author of this article.

\section{Ethical considerations}

The author confirms that the article submitted for publication is original. The work is not concurrently under consideration for publication in any other journals nor has it been published as a peer-reviewed publication.

\section{Funding information}

No grants or funding have been received to conduct this study.

\section{Data availability statement}

Data sharing is not applicable to this article as no new data were created or analysed in this study. 


\section{Disclaimer}

The views and opinions expressed in this article are those of the author and do not necessarily reflect the official policy or position of any affiliated agency of the author.

\section{References}

Adams, C. \& Bloom, M., 2017, 'Flourishing in Ministry: Wellbeing at work in helping professions, Journal of Psychology and Christianity, Batavia 36(3), 254-259.

AfriForum and Another v University of the Free State (CCT101/17) [2017] ZACC 48; 2018 (2) SA 185 (CC); 2018 (4) BCLR 387 (CC) (29 December 2017), viewed 21 June 2018, from http://www.saflii.org/cgi-bin/disp.pl?file=za/cases/ZACC/2017/48. html\&query $=$ Case $\% 20 C C T \% 20101 / 17$.

Akper, G.I., 2005, 'The role of the 'ordinary' reader in gerlad O. West's hermeneutic Scriptura', International Journal of the Bible, Religion and Theology in Southern Africa 88(1), 1-13.

Alexander, T.D. \& Baker, D.W., 2003, Dictionary of the Old Testament: Pentateuch A compendium of contemporary biblical scholarship., The IVP Bible Dictionary Series, InterVarsity Press, Downers Grove, IL, p 28, 30.

Azania, M.W., 2013, 'The black 'middle class and its white tendencies', Mail \& Guardian, viewed 20 December 2016, from http://thoughtleader.co.za/ malaikawaazania/2013/05/15/the-black-middle-class-and-its-white-tendencies/.

Bartz, J.A., Zaki, J., Bolger, N. \& Ochsner, K.N., 2011, 'Social effects of oxytocin in humans: Context and person matter', Trends in Cognitive sciences 15(7), 301-309. https://doi.org/10.1016/j.tics.2011.05.002

Batt, M., 2017, 'Open letter to CJ regarding official court language', Politicsweb viewed 25 April 2019, from http://www.politicsweb.co.za/documents/openletter-to-chief-justice-regarding-official-co.

Baumgartner, T., Fischbacher, U., Feierabend, A., Lutz, K. \& Fehr, E., 2009, The neura circuitry of a broken promise, Neuron 64(5), 756-770. https://doi.org/10.1016/j. neuron.2009.11.017

Beattie, J., 1980, 'Review article: Representations of the self in traditional Africa: La notion de personne en Afrique Noire', Africa 50(5): 313-320.

Bhengu, M.J., 1996, Ubuntu: The essence of democracy, Novalis Press, Cape Town.

Biwul, J.K.T., 2017, 'The use of hebel in Ecclesiastes: A political and economic reading', HTS Teologiese Studies/Theological Studies 73(3), a4571. https://doi. org/10.4102/hts.v73i3.4571

Block, E., 1949, The three years, Verlag: Urauchhaus, Stuttgart

Boyce-Tillman, J., 2007, 'Spirituality in the musical experience', in L. Bresler (ed.), Springer International Handbook of Research in Arts Education, pp. 1405-1422 Springer, Dordrecht, The Netherlands.

Brand, G., 2002, Speaking of a fabulous ghost: In search of theological criteria, with special reference to the debate on salvation in African Christian theology, Peter Lang, Oxford.

Brown, W.P., 2011, Ecclesiastes. Interpretation. A Bible Commentary for Teaching and Preaching, John Knox Press, Louisville, KY.

Carasik, M., 2003, Qohelet's Twists and Turns, Departmental Papers (Jewish Studies) University of Pennsylvania, 18, viewed 01 July 2018, from https://repository.
upenn.edu/cgi/viewcontent.cgi?referer=https://www.google.co.za/\&httpsredir= upenn.edu/cgi/viewcontent.cgi?referer=https://Wv
$1 \&$ article=1017\&context=jewishstudies_papers.

Chabalala, J., 2017, 'English will be only language of record in courts - Mogoeng' News24, viewed 23 June 2018, from https://www.news24.com/SouthAfrica/ News24, viewed 23 June 2018, from https://www.news24.com/SouthAfrica/
News/english-will-be-only-language-of-record-in-courts-mogoeng-20170929.

Christianson, E.S., 2007, Ecclesiastes through the centuries, Blackwell Publishing Ltd. Malden.

Chung, F., 2018, "'The time for reconciliation is over": South Africa votes to confiscate white-owned land', NZHerald, viewed 24 June 2018, from https://www.nzherald. co.nz/business/news/article.cfm?c_id=3\&objectid=12003693.

Comaroff, J. \& Comaroff, J.L., 2012, 'Theory from the South: Or, how Euro-America is evolving Toward Africa', Anthropological Forum 22(2), 113-131. https://doi.org/1 0.1080/00664677.2012.694169

Crespo, R. \& Mesurado, B., 2015, 'Happiness economics, eudaimonia and positive psychology: From happiness economics to flourishing economics', Journal of Happiness Studies, Springer 16(4), 931-946. https://doi.org/10.1007/s10902 014-9541-4

Dabrowska, J., Hazra, R., Ahern, T.H., Guo, J.D., McDonald, A.J., Mascagni, F. et al, 2011, 'Neuroanatomical evidence for reciprocal regulation of the corticotrophin-releasing factor and oxytocin systems in the hypothalamus and the bed nucleus of the stria terminalis of the rat: Implications for balancing stress and affect', Psychoneuroendocrinology 36(9), 1312-1326. https://doi. org/10.1016/j.psyneuen.2011.03.003

Desai, Z.K., 2012, 'A case for mother tongue education', PhD thesis, University of the Western Cape, Cape Town.

Desai, Z., 2016, 'Learning through the medium of English in multilingual South Africa: Enabling or disabling learners from low income contexts?', Comparative Education 52(3), 343-358. https://doi.org/10.1080/03050068.2016.1185259

Dube, M.W., 2006, 'Adinkra! Four hearts join together. On becoming healing-teachers of African Indigenous religion/s in HIV \& aids prevention', in I.A. Phiri \& S. Nadar (eds.), African women, religion, and health, pp. 131-156, Orbis Books, New York.
eNCA, 2018, SA healthcare system on verge of collapse: Health Ombudsman, eNCA viewed 23 June 2018, from https://www.enca.com/south-africa/watch-savealthcare-system-on-verge-of-collapse-health-ombudsman.

Enns, P., 2011, Ecclesiastes, Wm. B. Eerdmans Publishing, Grand Rapids, MI.

ExpatCapetown, 2018, Crime in South Africa. Expat, viewed 23 June 2018, from http:// www.expatcapetown.com/crime-in-south-africa.html.

Faulstick, D., 2014, “'Nothing New Under the Sun”: Ecclesiastes and the twentiethcentury-US-literary imagination', Doctor of Philosophy dissertation, Ohio University, Ohio.

Favor, C.A., 2004, 'Relational spirituality and social caregiving', Social Work 49(2), 241-249. https://doi.org/10.1093/sw/49.2.241

Feldman, R., 2012, 'Oxytocin and social affiliation in humans', Hormones and Behavior 61(3), 380-391. https://doi.org/10.1016/j.yhbeh.2012.01.008

Fitzgerald, C., 2009, 'From impasse to prophetic hope: Crisis of Memory', CTSA Proceedings 64, 21-42.

Fontaine, C.R., 2000, 'Wisdom traditions in the Hebrew Bible', Dialogue: A Journal of Mormon Thought 33(1), 101.

Fox, M.V., 1989, Qoheleth and his contradictions, Sheffield Academic Press, Sheffield, England.

Fox, M.V., 2010, A time to down and a time to build up: A rereading of Ecclesiastes, Wipf and Stock Publishers, Eugene, OR.

Frederiks, M., 2005, 'Hermeneutics from an Inter-religious perspective?', Exchange 34(2), 102-110. https://doi.org/10.1163/1572543054068587

Fredrickson, B.L. \& Losada, M.F., 2005, 'Positive affect and the complex dynamics of human flourishing', American Psychologist 60(7), 678-686. https://doi. org/10.1037/0003-066X.60.7.678

Froise, H., 2005, 'Religious dualism in South Africa: Consequences of inadequate mission theology of the spirit world', PhD thesis, University of the Free State, Bloemfontein.

Garfinkel, S., 2011, The Oxford encyclopedia of the books of the Bible, M. D. Coogan., Oxford University Press, Oxford, pp. 215-223.

Gehman, R.J., 2005, African traditional religion in biblical perspective, East African Educational Publishers, Nairobi.

Golka, F.W., 1993, The Leopard's Spots: Biblical and African Wisdom in Proverbs, T\&T Clark, Edinburgh, Scotland.

Granger, S. \& Maunier, F., 2008, Phraseology: An interdisciplinary perspective, John Benjamins Publishing Company, Philadelphia, PA.

Gureje, O., Lasebikan, V.O., Kola, L. \& Makanjuola, V.A., 2006, 'Lifetime and 12-month prevalence of mental disorders in the Nigerian Survey of Mental Health and WellBeing', The British Journal of Psychiatry 188, 465-471. https://doi.org/10.1192/ bjp.188.5.465

Hall, W.D., 2006, 'The economy of the gift: Paul Ricoeur's poetic redescription of reality', Literature and Theology 20(2), 189-204. https://doi.org/10.1093/litthe/ frl015

Hansenne, I., 2005, 'Thymic transcription of neurohypophysial and insulin-related genes: Impact upon T-cell differentiation and self-tolerance', Journal of
Neuroendocrinology 17(5), 321-327. https://doi.org/10.1111/j.1365-2826.2005. Neuroendoc

Harms, L.T.C., 2012, 'Law and language in a multilingual society', PER/PELJ 15(2), 20-31.

Healy, J. \& Sybertz, D., 1996, Towards an African narrative theology, Orbis, New York.

Hevi, J.K., 2004, The challenge of authenticity: African culture and faith commitment, Adonis \& Abbey Publishers Ltd., London.

Hlatshaneni, S., 2018, 'Driver's licences: “One in three illegal” due to scam', The Citizen, viewed 23 June 2018, from https://citizen.co.za/news/south-africa/1943673/ drivers-licences-one-in-three-illegal-due-to-scam/.

International Peace Institute, 2016, UN 2030: Rebuilding order in a fragmenting world. Chair's Report, Independent Commission on Multilateralism, New York City.

James, K.W., 1984, 'Ecclesiastes: Precursor of existentialists', The Bible Today 22, 85-90.

Jansen, J., 2013, 'Wrest power from English Tyranny', Mail \& Guardian, viewed 01 July 2018, from https://mg.co.za/article/2013-10-04-wrest-power-from-englishtyranny.

Jewkes, R., Abrahams, N. \& Mathews, S., 2009, Preventing rape and violence in South Africa: Call for leadership in a new agenda for action, MRC Policy Brief, pp. 1-2, Medical Research council, Pretoria.

King, C.S., 2003, Standing in the need of prayer: A celebration of Black Prayer, Free Press, New York.

Kirmayer, L.J., Brass, G.M. \& Tait, C.L., 2000, 'The mental health of aboriginal peoples: Transformations of identity and community', The Canadian Journal of Psychiatry Transformations of identity and community', The Canadian Journ
45, 607-616. https://doi.org/10.1177/070674370004500702

Knoetze, J.J., 2015, 'Spiritual transformation: Reaching and equipping Sub-Saharan African children', In die Skriflig 49(1), Art. \#1919, 1-8, viewed 29 December 2016, from http://www.indieskriflig.org.za/index.php/skriflig/articleview/1919/3238.

Kolk, B., 2015, 'The body keeps the score: Brain, mind, and body in the healing of trauma', The Permanente Journal 19(3), e118-e119.

Landgraf, R. \& Neumann, I.D. (eds.), 2008, Advances in vasopressin and oxytocin-from genes to behaviour to disease, vol. 170, Elsevier, Oxford, UK.

Lee, E.P., 2005, The vitality of enjoyment in Qohelet's theological rhetoric, Walter de Gruyter, New York. 
Lewis, C.S., 1955, Surprised by joy: The shape of my early life, Harcourt, Brace \& World, New York.

Lewis, N.D., 2018, What was the original language of the Bible? viewed 21 June 2018 from https://www.bibleodyssey.org/en/tools/bible-basics/what-was-theoriginallanguage-of-the-bible.

Lincoln, A.T., McConville, G. \& Pietersen, L.K. (eds.), 2013, The Bible and spirituality: Exploratory essays in reading scripture spiritually, Wipf and Stock Publishers, Eugene, OR.

Lohfink, N., 1990, 'Qoheleth 5:17-19 Revelation by Joy', The Catholic Biblical Quarterly 52(4), 625-635.

Lohfink, N., 2003, Qoheleth. A continental commentary, transl. S. McEvenue, Fortress Press, Minneapolis, MN.

Lombaard, C., 2003, 'The Old Testament in Christian spirituality: Perspectives on the undervaluation of the Old Testament in Christian spirituality', HTS: Theological undervaluation of the
Studies 59(2), 433-450.

Lombaard, C., 2011, 'Biblical spirituality and interdisciplinarity: The discipline at cross methodological intersection 1 ', Religion and Theology 18(1-2), 211-225. https:// doi.org/10.4102/hts.v59i2.658

Lombaard, C., 2015, 'Biblical spirituality and transformation', In die Skriflig 49(2), 1-6. https://doi.org/10.4102/ids.v49i2.1950

Long, W.M., 2000, Health, healing and God's Kingdom: New pathways to Christian Health Ministry in Africa, Regnum Books International, Carlisle, CA.

Longman, T. III \& Enns, P., 2008, Dictionary of the Old Testament: Wisdom, poetry \& writings. InterVarsity Press, Nottingham, England.

Louw, D., 2012, Network of the human soul, Sun Media, Stellenbosch.

Macciò, A., Madeddu, C, Chessa, P, Panzone, F, Lissoni, P, \& Mantovani, G., 2010, 'Oxytocin both increases proliferative response of peripheral blood lymphomonocytes to phytohemagglutinin and reverses immunosuppressive estrogen activity', In Vivo 24(2), 157-163.

Magesa, L., 2010, African religion in the dialogue debate: From intolerance to coexistence, LIT Verlag GmbH and Co., Münster.

Magwaza, A.S. Magwaza, A.S., Killian, B.J., Petersen, I. \& Pillay, Y., 1993, 'The effects of chronic violence on preschool children living in South African townships, Child Abuse \& Neglect 17(6), 795-803. https://doi.org/10.1016/S0145 2134(08)80010-5

Maluleke, T.S., 1996, 'Black and African theologies in the new world order: A time to drink from our own wells', Journal of theology for Southern Africa 96, 3-19.

Manala, M.J., 2006, 'The churches ministry to the sick in a black South African context', Doctor of Theology dissertation, University of South Africa, Pretoria.

Marais, C., 2016, 'Caring and connectedness in the context of domestic worker employment in South Africa', Journal of Psychology in Africa 26(3), 237-245. https://doi.org/10.1080/14330237.2016.1185903

Masango, M.J.S., 2006, 'African spirituality that shapes the concept of Ubuntu', Verbum at ecclesia 27(3), 930-943. https://doi.org/10.4102/ve.v27i3.195

Mashau, T.D., 2016, 'Moving to different streams of healing praxis: A reformed missionary approach of healing in the African context, Verbum et Ecclesia 37(1) 1-8. https://doi.org/10.4102/ve.v37i1.1508

Mbiti, J., 2013, Life with dignity in Africa: Theological perspectives', God of Life, lead Africa to, Peace, Justice and Dignity, Report of the 10th Assembly of the All African Conference of Churches, AACC, Kampala.

McCabe, R.V., 1996, 'The message of Ecclesiastes', DBSJ 1, 85-112.

McConville, J.G., 2013, 'Spiritual formation in the Psalms', in A.T. Lincoln, G. McConville \& L.K. Pietersen (eds.), Exploratory essays in reading scripture spiritually, pp. 56-74, Cascade Books, Eugene, OR.

McEwan, C., 2003, 'Building a postcolonial archive? Gender, collective memory and citizenship in post-apartheid South Africa', Journal of Southern African Studies 29, 739-757. https://doi.org/10.1080/0305707032000095009

Moon, W.J., 2009, African proverbs reveal Christianity in culture: A narrative portraya of Builsa proverbs contextualizing Christianity in Ghana, Pickwick Publications, Eugene, OR.

Moschella, M.C., 2012, Calling and compassion: Elements of joy in lived practices of care. Yale Center for Faith \& Culture consultation on "Joy and Human Flourishing", Connecticut, New Haven, CT.

Mulago, V., 1991, 'Traditional African Religion and Christianity', in J.K. Olupona (ed.), African Traditional Religion in contemporary society, pp. 119-134, Paragon House, New York.

Murphy, R.E., 2018, Ecclesiastes, vol. 23A, World Books, Dallas, TX.

Mwombeki, F.R., 2001, 'Reading the Bible in contemporary Africa', Word and World 21(2), 121-128.

Nengovhela, R.E., 2010, 'The role of symbolism in the Tshivenda discourse: A semantic analysis', Master's Degree, School of Languages and Communication Studies, University of Limpopo.

Neumann, I.D., 2008, 'Brain oxytocin: A key regulator of emotional and social behaviours in both females and males', Journal of Neuroendocrinology 20(6) 858-865. https://doi.org/10.1111/j.1365-2826.2008.01726.x

Ngong, D.T., 2010, The Holy Spirit and Salvation in African Christian Theology: Imagining a more hopeful future for Africa, Peter Lang Publishers, New York.

Nomlomo, V., 2008, 'IsiXhosa as a medium of instruction in Science teaching in primary education in South Africa: Challenges and prospects', in M. Qorro, Z. Desai \& B. Brock-Utne (eds.), LOITASA: Reflecting on Phase 1 and entering Phase 2, pp.81-101, E\&D Vision Publishing Limited, Dar es Salaam.
Nomlomo, V., 2009, Science teaching in English and isiXhosa: Languages of Instruction, VDM Verlag, Saarbrucken.

Ong, H., 2012, 'Language choice in Ancient Palestine: A sociolinguistic study of Jesus' language use based on Four "I have come" sayings', BAGL 1, 63-101.

Onwu, N., 1987, 'The Eucharist as covenant in the African context', Africa Theologica Journal 16, 151-52.

Paynter, N., 2003, Blessed be our table: Graces for mealtimes and reflections on food, Wild Goose Publications, Glasgow.

Pennington, J., 2015a, The Universality of Human Flourishing, viewed 30 June 2018, from https://tifwe.org/wp-content/uploads/2015/03/A-Biblical-Theologyof-Human-Flourishing-Pennington.pdf.

Pennington, J., 2015b, A Biblical theology of human flourishing, Institute for Faith Work and Economics, McLean, VA, viewed 27 June 2018, from http://tifwe. org/wp-content/uploads/2015/03/Pennington-A-Biblical-Theology-of-Humanorg/wp-content/urishing.pdf.
Flourish

Perdue, L.G., 2008, The sword and the stylus: An introduction to wisdom in the age of empires, William B Eerdmans Publishing Company, Grand Rapids, MI.

Perry, T.A., 1993, Dialogues with Kohelet: The book of Ecclesiastes: Translation and commentary, Pennsylvania State University Press, University Park, PA.

Peters, G., 2013, 'Spiritual theology. A Historical view', in J. Goggin \& K. Strobe (eds.), Reading the Christian spiritual classics: A guide for evangelicals, pp.79-94, InterVarsity Press, Downers Grove, IL.

Platinga, C., 1995, Not the way it's supposed to be. A Breviary of sin, Wim B. Eerdmans Publishing Co., Grand Rapids, MI.

Pobee, J.S., 1997, 'Proverbs and African Christianity', Paper presented at the Consultation on African Proverbs and Christian Mission at Ricatla Theological Seminary, 27-31 March 1995, Ricatla Theological Seminary, Maputo, Mozambique.

Property 24, 2018, 'What does 2018 hold for SA's property market?', Propert 24, viewed 23 June 2018, from https://www.property24.com/articles/what-does2018-hold-for-sas-property-market/26936.

Richards, L.O., 2016, New International encyclopedia of Bible words, Zondervan, Grand rapids, MI.

Ricoeur, P., 1977, 'Toward a Hermeneutic of the idea of revelation', The Harvard Theological Review 70(1/2), 1-37. https://doi.org/10.1017/\$0017816000017600

Sakati, P.P., 2016, 'Exploring the use of mother tongue as the medium of instruction in Grade 4: A case study of four schools in the East London district', Master of Education, Faculty of Education, University of Fort Hare, Grahamstown.

Schneiders, S., 2005, 'Biblical foundations of spirituality', in E.J. Mahoney (ed.), Scripture as the Soul of Theology, pp. 1-22, Liturgical Press, Coleggeville, PA.

Sekine, S., 1999, Transcendency and symbols in the Old Testament. A Genealogy of the hermeneutical Experiences, Walter de Gruyter, Berlin.

Seow, C., 2008, 'Wisdom during the Ptolemaic empire: The Book of Qoheleth', in L.G. Perdue (eds.), The sword and the stylus: An introduction to wisdom in the age of empires, pp. 198-255, William B. Eerdmans Publishing Company, Grand Rapids, MI.

Sfumato, 2017, 'The Meaning of "Sfumato"', Sfumato, viewed 24 June 2018, from https://sfumatofragrances.com/blogs/news/what-does-sfumato-mean.

Spolsky, B., 2014, The languages of the Jews: A sociolinguistic history, Cambridge University Press, Cambridge, UK.

Steenkamp-Nel, A., 2018a, 'Shifting landscapes: Spirituality in the life of the African healthcare volunteer', in A. de la Porte, N. Joubert \& A. Oberholzer (eds.), Proceedings of the 2nd Biennial South African Conference on Spirituality and Healthcare, pp. 261-277, Cambridge Scholars Publishing, Newcastle, UK.

Steenkamp-Nel, A.E., 2018b, 'African spirituality in transformation: Fragments and fractures of the shifting sacred', HTS Teologiese Studies/Theological Studies 74(3), 4941. https://doi.org/10.4102/hts.v74i3.4941

Steenkamp-Nel, A.E., 2018c, 'Spiritual transformation in South African healthcare: Messiness, Mastery and Method'. Manuscript submitted for publication.

Steenkamp-Nel, A.E., 2019, 'Transformative joy in Qohelet: A thread that faintly Glistens', HTS Teologiese Studies/Theological Studies 75(3), a5126. https://doi. org/10.4102/hts.v75i3.5126

Stein, D.J., Phillips, K.A., Bolton, D., Fulford, K.W., Sadler, J.Z. \& Kendler, K.S., 2010 'What is a mental/psychiatric disorder? From DSM-IV to DSM-V', Psychological Medicine 40, 1759-1765. https://doi.org/10.1017/S0033291709992261

Steindl-Rast, D., 1984, Gratefulness, the Heart of Prayer: An approach to life in fullness, Paulist Press, New York.

Stevenson, A., 2010, 'Fulcrum', in A. Stevenson (ed.), Oxford Dictionary of English, 3rd edn., p. 760, Oxford University Press, Oxford.

Strong, J., 1890, A concise dictionary of the words in the Hebrew Bible, Abingdon Press, Nashville, TN.

Sypnowich, C., 2018, 'Flourishing children, flourishing adults: Families, equality and the neutralism-perfectionism debate', Critical Review of International Social and Political Philosophy 21(3), 314-332. https://doi.org/10.1080/13698230.2017.13 98477

TimesLive, 2018, 'SA road carnage a "national crisis"', Sunday Times, viewed 23 June 2018, from https://www.timeslive.co.za/news/south-africa/2018-04-24-sa-roadcarnage-a-national-crisis/.

Tsimane, E., 2010, 'Black to the Past', Sunday Standard, 19 August 2010, viewed 01 July 2018, from http://www.sundaystandard.info/black-past. 
UNFPA, 2016, Enhancing human flourishing within the 2030 development agenda: The spirituality of global transformation, United Nations Population Fund, New York City, viewed 18 February 2016, from http://stephengpost.com/downloads/ UNFPA\%20Enhancing\%20Human\%20Flourishing.pdf

Unger, M.F., 2005, The new Unger's Bible handbook, Moody Publishers, Chicago, IL, pp. $248-250$.

United Nations, 2015, Transforming our World: The 2030 agenda for sustainable development. A/RES/70/1, United Nations, New YorkCity, viewed 30 June2018, from https://sustainabledevelopment.un.org/content/documents/21252030\%20 Agenda $\% 20$ for $\% 20$ Sustainable $\% 20$ Development $\% 20$ web.pdf

Van den Hoogen, T., 2011, A Taste of God: On spirituality and reframing foundational theology, LIT Verlag, Berlin.

Van Dyk, G.A.J. \& Nefale, M.C., 2005, 'The split-ego experience of Africans: Ubuntu therapy as a healing alternative', Journal of Psychotherapy Integratio 15(1), 48-66.

Van Heerden, W., 2006, “It's on the old mat that one weaves the new one": The dialogue between African proverbs and biblical texts', Old Testament Essays 19(2), 429-440

Van Selms, A., 1951, Arabies-Afrikaansche Studies -'n tweetalige (Arabiesen Afrikaans) kategismus, N.V. Noord Hollandsche Uitgewers \& Royal Netherlands Academy for Sciences (Literature Division), Leiden.

Van Staden, S. \& Howie, S., 2012, 'Reading between the lines: contributing factors that affect Grade 5 student reading performance as measured across South Africa's 11 languages', Educational Research and Evaluation 18(1), 85-98. https://doi.org/10 .1080/13803611.2011.641270
Van Zyl, G., 2017, 'Looting, cadre deployment leave little for maintaining collapsing infrastructure', BizNews, viewed 23 June 2018, from https://www.biznews.com/ undictated/2017/10/17//ooting-cadre-deployment-infrastructure/.

Waaijman, K., 2000, Spiritualiteit: vormen, grondslagen, methoden, KokUitgeverij, Kampen.

Waaijman, K., 2002, Spirituality: Forms, foundations, structures, Peeters Publishers, Leuven.

Waaijman, K., 2006, 'Conformity in Christ', Acta Theologica 27(8), 41-53.

Waaijman, K., 2007, 'Spirituality - A multifaceted phenomenon. Interdisciplinary explorations', Studies in Spirituality 17, 1-113. https://doi.org/10.2143/SIS.17. 0.2024643

Walsh, J.T., 1982, 'Despair as a theological virtue in the spirituality of Ecclesiastes', Biblical Theology Bulletin: Journal of Bible and Culture 12(2), 46-49. https://doi. org/10.1177/014610798201200203

West, G.O., 1992, 'Some parameters of the hermeneutical debate in the South African context', Journal of Theology for Southern Africa 80, 3-13.

West, G.O., 1997, 'On the eve of an African biblical studies: Trajectories and trends', Journal of Theology for Southern Africa 99, 99-115.

Willis, W.B., 1998, The Adinkra Dictionary. A visual pimer on the language of Adinkra, Pyramid Complex, Washington, DC.

Zamarron, R., 2013, 'Joy, Tradition, African Culture in Liturgy', National Catholic Register, viewed 29 December 2016, from http//www.ncregister.com/blog/ rachel-zamarron/joy-tradition-african-culture-in-.

Zimmermann, F., 1973, The Inner World of Qohelet, KTAV, New York. 